\title{
Breast cancer and fertility preservation
}

\author{
S. Samuel Kim, M.D. ${ }^{a}$, Jennifer Klemp, Ph.D. ${ }^{b}$, and Carol Fabian, M.D. ${ }^{b}$ \\ a Division of Reproductive Endocrinology and Infertility, University of Kansas School of Medicine, \\ Kansas City, Kansas \\ b Division of Medical Oncology, University of Kansas School of Medicine, Kansas City, Kansas
}

\begin{abstract}
Objective-To review the benefits of adjuvant systemic therapy given to women with breast cancer of reproductive age, its effects on fertility, and options for fertility preservation.

Design-Publications relevant to fertility preservation and breast cancer were identified through a PubMed database search.

Conclusion(s)-Most women who develop invasive breast cancer under age 40 will be advised to undergo adjuvant chemotherapy with or without extended antihormonal therapy to reduce the risk of recurrence and death from breast cancer. Adjuvant chemotherapy particularly with alkylating agents such as cyclophosphamide is gonadotoxic and markedly accelerates the rate of age-related ovarian follicle loss. Although loss of fertility is an important issue for young cancer survivors, there is often little discussion about fertility preservation before initiation of adjuvant therapy. Greater familiarity with prognosis and effects of different types of adjuvant therapy on the part of infertility specialists and fertility preservation options such cryopreservation of embryos, oocytes, and ovarian tissue on the part of oncologists would facilitate these discussions. Establishment of rapid fertility consultation links within cancer survivorship programs can help ensure that every young woman who is likely to undergo gonadotoxic cancer treatment is counseled about the effects of therapy and options available to her to increase the likelihood of childbearing after cancer treatment.
\end{abstract}

\section{Keywords}

Breast cancer; fertility preservation; embryo cryopreservation; oocyte cryopreservation; ovarian tissue cryopreservation; ovarian transplantation; GnRH agonist; chemotherapy; cancer survivorship

In the United States, $5 \%-7 \%$ of cases of invasive breast cancer $(\sim 11,000 /$ year $)$ occur in women who are under age 40 at diagnosis (www.seer.cancer.gov.2008), most between the ages of 30 and 40 (1). As almost one quarter of first live births in the United States occur between the ages of 30 and 40, many of these women will not have had the opportunity to bear a child (2). Less than $10 \%$ of women who develop invasive breast cancer under age 40 have children postdiagnosis (3-5), despite survey results suggesting about half desire to do so (6) and observational studies that do not indicate an increased risk of relapse or death for women who become pregnant after a breast cancer diagnosis (7-9). Receipt of cytotoxic chemotherapy is a major factor in the low rate of live births after a diagnosis of breast

Copyright $@ 2011$ American Society for Reproductive Medicine, Published by Elsevier Inc.

Reprint requests: S. Samuel Kim, M.D., Department of Obstetrics and Gynecology, Kansas University Medical Center, 3901 Rainbow Boulevard, Kansas City, Kansas 66160 (skim2@kumc.edu)..

S.S.K. has nothing to disclose. J.K. has nothing to disclose. C.F. has nothing to disclose. 
cancer. Two-thirds of women $<40$ years at diagnosis will have a tumor is $>2 \mathrm{~cm}$ in size and/ or involved axillary lymph nodes (stage II or higher) (10). Almost all women with stage II tumors and even most with stage I disease with a tumor greater than $1 \mathrm{~cm}$ in size will be advised to have gonadotoxic chemotherapy (11). At least two-thirds of women under 40 will have a hormone receptor positive tumor and in addition to chemotherapy (or as a single modality in women with favorable tumors) will be advised to undergo 5 years of antihormone therapy with a tamoxifen \pm a GnRH agonist.

Amenorrhea is therapeutically desirable as achievement of even temporary amenorrhea is known to reduce recurrence and improve survival (12-15). Thus, at best women with small favorable tumors undergoing antihormonal therapy alone will have childbearing delayed by 5 years or more, which for women in their 30 s can reduce the chance of having a child, and at worst cytotoxic chemotherapy will significantly add to age-related follicular depletion. Even women who regain menses after cytotoxic chemotherapy \pm antihormonal therapy are likely to have undergone significant follicle depletion and reproductive aging of 10 years or more (16-19). As mortality from breast cancer including breast cancer under the age of 40 continues to decrease $(20,21)$, fertility preservation has become a major survivorship issue for young women developing breast cancer (22-25).

Classically, fertility preservation procedures are performed in the 2-4 week interval between surgical removal of the tumor and initiation of adjuvant chemotherapy. Depending on where a woman is in her menstrual cycle at the time of referral to the fertility specialist, initiation of adjuvant chemotherapy may not need to be delayed or can be delayed for 2-4 weeks. Increasingly, neoadjuvant therapy is given before surgery for women with clinically positive nodes or a $2 \mathrm{~cm}$ or greater tumor as these women are likely to harbor micro-metastases. Response to neoadjuvant therapy is prognostic, and receipt of all chemotherapy before surgery in women undergoing mastectomy allows immediate reconstruction without delay in initiating adjuvant treatment (26). Unfortunately, use of neoadjuvant therapy further complicates fertility preservation attempts in that the window for optimal preservation between diagnosis and initiation of gonadotoxic treatment is dramatically narrowed, and the tumor is still in place during follicle stimulation, which makes many oncologists uncomfortable particularly if the woman has estrogen receptor-positive tumors.

The initial focus of most oncologists is mapping out the most successful cancer treatment strategy, particularly when dealing with women of reproductive age who often present with a more advanced stage and have a worse prognosis than their older counterparts $(1,27,28)$. As a consequence, many young cancer patients fail to receive the information to engage informed decision making about preserving their fertility (29). Only half of young women feel that their concerns about fertility are addressed adequately at the time of a breast cancer diagnosis (6). Failure to discuss fertility fuels later feelings of grief and regret (22-25). Therefore, it is important to address issues related to fertility preservation options at the time discussions of type and sequencing of gonadotoxic cancer treatment are taking place. Key questions likely to be posed include [1] how is adjuvant treatment selected; [2] how much will adjuvant treatment reduce risk for recurrence or death from breast cancer?; [3] what is the chance that adjuvant therapy will result in loss of fertility and how can this risk be minimized?; [4] will any of the fertility preservation procedures or pregnancy result in higher risk of relapse; and [5] what are the fertility preservation options and how would they be inserted into the breast cancer treatment plan?

This review will focus on fertility preservation options for breast cancer patients, types of adjuvant therapy currently prescribed, and their relative effects on fertility and breast cancer recurrence. Importantly, we will make some practical suggestions on how to interdigitate 
fertility preservation into the treatment plan for young women newly diagnosed with breast cancer.

\section{HOW IS ADJUVANT TREATMENT SELECTED?}

Adjuvant treatment is selected based on both the risk of recurrence and the biologic characteristics of the tumor. The 15-year risk of recurrence and death for women under 50 not receiving adjuvant systemic therapy is $53 \%$ and $42 \%$, respectively, irrespective of stage or biologic characteristics according to Early Breast Cancer Trialists (EBCTCG) metaanalyses with the latest major published outcomes in 2005 (30). These figures dramatically differ by stage and bio-marker variables, with a $12.5 \%$ breast cancer mortality rate at 15 years for women under 50 with low-risk node-negative tumors, $25 \%$ for women with highrisk node-negative tumors, and 50\% for node-positive tumors (30). For breast cancer, 15year recurrence and survival rate figures are useful when comparing adjuvant treatment outcomes, since breast cancer can recur 10 years or more after initial diagnosis and women generally live for years after a diagnosis of metastatic disease. Breast cancer mortality rates at 15 years are about half of those at 5 years (30). Biologic characteristics with the greatest impact on treatment selection include estrogen and progesterone receptors (ER and PR), proliferation (usually measured by Ki-67), and presence of the growth factor receptors, such as HER-2 neu (31).

Based on constellations of these receptors, proliferation, and changes in other genes, breast cancers are now often described as [1] luminal A (strongly ER+, PR+, low Ki-67, and growth factor receptor-negative); [2] luminal B (ER or PR+ but one or more unfavorable characteristics such as high Ki-67 or expression of other growth factor receptors including EGFR and HER-2); [3] HER-2+ and ER-; and [4] basal-like (which includes triple negative; Table 1). Without regard to age, luminal A comprise $\sim 15 \%$ of cancers, luminal B $60 \%$, HER-2+ and ER-10\%, and basal-like $15 \%(31,32)$. Young women more frequently have HER-2+ and basal-like tumors than older women.

The mainstay of systemic adjuvant therapy for young women with luminal A tumors is antihormonal therapy such as tamoxifen (a selective estrogen receptor modulator) for 5 years with or without suppression of ovarian function $(\mathrm{GnRH}$ agonist such as goserelin or oohorectomy). It is unclear whether chemotherapy aside from reduction of hormonal output in premenopausal women improves the prognosis for luminal A cancers. In Europe and Canada, women with luminal A tumors often receive only antihormonal therapy \pm ovarian suppression, but in the United States they are likely to be offered chemotherapy as well, particularly if they are under age 40 at diagnosis. Women with luminal B tumors are usually advised to receive chemotherapy in addition to antihormonal therapy $(31,32)$. Gene expression array panels are available to make the distinction between luminal A and B and to determine which ER+ women are likely to benefit from chemotherapy in addition to antihormonal therapy (33-36).

All women with hormone receptor negative tumors $>1 \mathrm{~cm}$ in size will be advised to take adjuvant chemotherapy. Even women with tumors $<1 \mathrm{~cm}$ will often be offered adjuvant chemotherapy if their tumors are high grade and/or HER-2+. Women with HER-2+ tumors will also be offered trastuzumab for up to a year (37).

Disease-free survival rates during the first 5 years decrease progressively for women with luminal A, luminal B, HER-2+, and basal-like tumors (31). Although women with Her-2+ and basal-like tumors (which are usually hormone receptor negative) have a higher relapse rate in the first 5 years after diagnosis than the comparable stage of luminal A and B (which are usually hormone receptor positive), the luminal A and B tumors have a higher rate of late relapse (38). Consequently, premenopausal women with ER+ tumors at high risk of 
eventual relapse due to large tumor size and or positive axillary nodes who become postmenopausal during their initial 5 years of treatment with tamoxifen \pm chemotherapy may be offered extended endocrine therapy with an aromatase inhibitor (39), whereas highrisk women with ER- tumors or unfavorable ER+ tumors (luminal B) may be offered a longer course or more cytotoxic agents, thereby reducing the chance of fertility after adjuvant treatment for breast cancer.

\section{HOW MUCH WILL ADJUVANT THERAPY REDUCE RISK FOR RECURRENCE AND DEATH FROM BREAST CANCER?}

In general, adjuvant therapy in premenopausal women appropriately tailored to disease characteristics is likely to reduce the risk of recurrence and death from breast cancer by a relative factor of $50 \%$ or more (30). Early generation adjuvant chemotherapy regimens such as 6-12 cycles of cyclophosphamide, methotrexate, and fluorouracil (CMF) or four cycles of an anthracycline and cyclophosphamide (AC) suggest an approximate $40 \%$ reduction in recurrence and one-third reduction in 15-year breast cancer mortality (30). These chemotherapy regimens may still be given today for women with node-negative low-risk disease. The addition of an anthracycline-containing regimen to 5 years of tamoxifen in women under 50 reduced mortality by $57 \%$ (30). Second-generation regimens such as 6 months of fluorouracil, epirubicin, and cyclophosphamide (FEC) or fluorouracil, adriamycin (doxorubicin), and cyclophosphamide (FAC) is associated with a relative reduction of $44 \%$ in 15-year mortality. Tamoxifen alone reduces mortality by $\sim 30 \%$ for ER+ women under 50 and by $40 \%$ for those under 40 . For women under 50 with an ER+ tumor, the addition of 5 years of tamoxifen to an anthracycline-containing regimen reduced mortality by a relative factor of $57 \%(30)$.

Taxanes provide incremental benefits when given with adjuvant anthracyclines and cyclophosphamide to risk-eligible women with all but luminal A cancers $(32,40)$. Overall, a $3 \%$ absolute increase in survival is observed if taxanes are added to an anthracycline and cyclophosphamide regimen (41). Regimens most commonly used today add a taxane to an anthracycline and cyclophosphamide. This may be done adding the taxane to a reduced dose of the anthracycline and cyclophosphamide (the so-called TAC regimen, which is usually given for six cycles) or giving four cycles of AC followed by four cycles of every 3 weeks taxane or every 2 weeks taxane or 12 doses of a weekly taxane.

Trastuzumab (herceptin) given during and after chemotherapy or chemohormonal therapy further improves relapse-free and overall survival by about $50 \%$ in women with HER-2+ tumors (37). Intravenous bisphosphonates given every 3-6 months for 2-3 years appear to reduce recurrence by about one-third in premenopausal women with ER+ tumors given antihormonal therapy with tamoxifen and ovarian suppression with a GnRH agonist (goserelin) (42).

\section{WHAT ARE THE CHANCES THAT TREATMENT WILL INDUCE AMENORRHEA OR LOSS OF FERTILITY}

The primary determinants of chemotherapy-induced amenorrhea and/or loss of fertility are age of the woman at the time of chemotherapy, dose and number of cycles of the alkylating agent received, and, to a lesser extent, exposure to anthracyclines, taxanes, and platinum analogs (16-19). The aklylating agent, cyclophosphamide, is one of the oldest and most effective drugs used in adjuvant therapy for breast cancer but is also one of the most potent in reducing ovarian follicular reserve. A woman who takes the equivalent of $2.4-3 \mathrm{~g} / \mathrm{m}^{2}$ of cyclophsophamide over 12-16 weeks can count on adding an approximate 10 years to her ovarian reproductive age or 1.5-3.0 years per cycle (16-19). A woman who is 30 at 
chemotherapy initiation may have an equivalent ovarian age of 40 after 4-6 cycles of cyclophosphamide containing polychemotherapy. Women with a good prognosis breast cancer (stage I node negative) who received either six cycles of CMF or four cycles of AC experienced an estimated 33\% rate of amenorrhea (43-47). Rates of amenorrhea for more aggressive regimens given to women with poorer prognosis tumors such as six cycles of fluorouracil plus epirubicin or doxorubicin and cyclophosphamide (FEC or FAC), six cycles of $\mathrm{AC}$ or four cycles of $\mathrm{AC}$ followed by four of docetaxel are higher ranging from $50 \%$ to $65 \%$ (48-52). Fifteen to 50 percent of women younger than age 40 at diagnosis will recover menses. Amenorrhea is likely to be permanent in $90 \%$ of women over 40 and in $95 \%$ of women over 45 (50-53).

\section{ALTERNATIVE CHEMOTHERAPY TREATMENT REGIMENS THAT MAY REDUCE FOLLICULAR DAMAGE}

Chemotherapy regimens can usually be altered somewhat to reduce gonadotoxicity. For example, for luminal B tumors, three cycles of FEC followed by three cycles of docetaxel provides similar chemo-therapeutic efficacy as six cycles of FEC with less ovarian damage due to reduced amount of the alkylating agent (54). For most Her-2+ tumors, preliminary evidence suggests that taxane and carboplatin are as effective as anthracycline, cyclophosphamide, and taxane combinations, completely avoid cyclophosphamide, and are probably not as likely to result in sterility $(55,56)$. Triple negative breast cancers (ER-, PR -, Her-2 negative) often have multiple deficits in DNA repair pathways, and women with these tumors may selectively benefit from treatment with cis- or carboplatin regimens in combination with Poly-(ADP-ribose) polymerase (PARP) inhibitors (57). Trials are ongoing, but again platin-based regimens in combination with PARP are likely to be less gonadotoxic than cyclophosphamide-based regimens.

\section{WILL PREGNANCY AFTER A BREAST CANCER DIAGNOSIS INCREASE THE CHANCE OF RECURRENCE AND MISCARRIAGE?}

Becoming pregnant after a diagnosis of breast cancer does not appear to result in worse outcomes in case-control studies or cohort studies $(4,5,7,8)$. In fact, in several series, pregnancy after a diagnosis of breast cancer appeared to result in a reduced risk of relapse (7-9), particularly for women who waited for 2 years after diagnosis to conceive (9). A theoretical risk for women undergoing ovarian harvest before chemotherapy and later reimplantation (see below) is reintroduction of viable tumor cells micrometastatic to the ovary at diagnosis. Serial sectioning of the ovary after prophylactic oophorectomy suggests that the chance of this occurring in women without clinical systemic metastases at diagnosis is $<1 \%(58,59)$.

When comparing pregnancy outcomes in women with a history of breast cancer and controls, miscarriage occurred in $24 \%$ of the patients who become pregnant, compared with $18 \%$ of the controls (women without breast cancer). The age-adjusted relative risk of miscarriage in the first 20 weeks of a given pregnancy associated with a history of breast cancer was 1.7 (95\% confidence interval [CI], 1.1-2.80) (7).

\section{FERTILITY PRESERVATION OPTIONS FOR WOMEN WITH BREAST CANCER}

Currently available fertility preservation options in breast cancer patients (Fig. 1) include the use of GnRH analogs, controlled ovarian stimulation (COS) with cryopreservation of mature oocytes or embryos, cryopreservation of immature oocytes or in vitro maturation followed 
by cryopreservation of mature oocytes, and cryopreservation of ovarian tissue. Additional options include donor egg IVF, surrogacy, or adoption.

\section{GnRH AGONISTS (GnRHa)}

It is still controversial whether GnRH agonists or antagonists can protect human oocytes from gonadotoxic dose of chemotherapy. Nevertheless, a number of human studies published to date support the protective effect of GnRH agonists, but they are either nonrandomized or small sample sized.

Badawy et al. reported in women receiving adjuvant chemotherapy for breast cancer who were randomized to receive a GnRHa (goserelin $3.6 \mathrm{mg}$ ) versus no GnRHa (60) that the development of premature ovarian failure was significantly lower in the GnRHa cotreatment group compared with the control group ( $11.4 \%$ vs. $66.6 \%$, respectively). The study demonstrated that GnRHa cotreatment may preserve post-treatment ovarian function in women under 40 years with breast cancer. However, the follow-up period of this study was too short.

To date, three prospective, randomized, controlled studies with GnRHa have been published, but none of them were adequately powered. According to our meta-analysis of 11 prospective studies (three randomized and eight nonrandomized) (60-70), GnRHa cotreatment during chemotherapy appeared to be associated with increased odds of maintaining ovarian function post-treatment (odds ratio 10.57; 95\% CI, 5.22-21.39) (71). However, separate analysis of the three prospective randomized studies $(60,69,70)$ failed to prove the statistically significant protective effects of GnRHa cotreatment. It will require a large prospective randomized study to determine whether GnRHa can truly protect human ovarian function. In the United States, the first large clinical trial evaluating the effects of a GnRHa in women with hormone receptor-negative breast cancer who receive chemotherapy is being conducted by the Southwest Oncology Group (SWOG).

\section{EMBRYO CRYOPRESERVATION}

Embryo cryopreservation is a clinically well established technique. According to Society for Assisted Reproductive Technologies, the current live-birth rate per transfer using frozenthawed embryos is $35.6 \%$ in U.S. women under 35 years old (http://www.sart.org, 2008). As most fertility preservation options are experimental, embryo cryopreservation should initially be considered if there is adequate time for ovarian stimulation and a partner or donor sperm is available. The process of embryo cryopreservation requires ovarian stimulation, oocyte retrieval, and IVF, which normally takes $2-5$ weeks. It may not be applicable to all cancer patients, especially those who require immediate cancer treatment. In addition, exposure to a high estrogen milieu during ovarian stimulation with gonadotropin may not be safe for women with ER+ breast cancer owing to the potential for accelerated tumor growth seen in animal studies (72). However, there is an ongoing debate as to whether a short-term increase in hormones as a result of COS results in an increase in the risk of breast cancer.

\section{PREVENTION OF THE ELEVATED SERUM $E_{2}$ LEVELS WITH COS IN BREAST CANCER PATIENTS}

Although the natural cycle IVF does not increase serum $E_{2}$ levels above the physiologic levels, it is not a realistic option for fertility preservation in cancer patients as the embryo yield per cycle is too low and there is no time for multiple IVF cycles in most cases.

Conventional ovarian stimulation protocols for IVF treatment is also problematic in breast 
cancer patients, as the significant increase in peak serum $\mathrm{E}_{2}$ levels may adversely affect the process of tumor growth. Alternative approaches in breast cancer patients can be COS with tamoxifen or letrozole alone or concurrently with gonadotropins.

Tamoxifen, a selective estrogen receptor modulator, is widely used for treatment and prophylaxis of breast cancer. In addition, it has been effectively used for ovulation induction and COS. When compared with natural cycle IVF, COS with tamoxifen yielded more embryos, but the pregnancy rate was not enhanced (73). Aromatase inhibitors have also been used for ovarian stimulation. Letrozole is a potent third generation aromatase inhibitor that competitively inhibits the activity of aromatase enzyme in estrogen receptor-positive cells and suppresses estrogen production. Letrozole is effective not only for adjuvant hormonal therapy for breast cancer but also for ovulation induction.

Although tamoxifen or letrozole can induce ovulation or stimulate follicular growth, it does not generate enough follicles for embryo cryopreservation. To make it a more practical method, use of low-dose gonadotropin in combination with tamoxifen or letrozole has been attempted with good results (73). In terms of peak $E_{2}$ levels, ovarian stimulation with letrozole plus a gonadotropin resulted in much lower levels compared with tamoxifen plus a gonadotropin. Moreover, when letrozole plus gondadotropin is use for COS, recurrence rates of breast cancer do not appear to be increased at 2 years of follow-up (74).

\section{COS FOR IVF IN BREAST CANCER PATIENTS}

The goals for COS in breast cancer patients should be [1] to minimize the elevation of $\mathrm{E}_{2}$ levels during a stimulation cycle, [2] to shorten the course of COS, and [3] to maximize the number of oocytes. To achieve these goals, a protocol of letrozole in combination with gonadotropin $(\mathrm{rFSH})$ appears to be most practical to date. Although it is too early to prove the safety as well as efficacy of this protocol in women with breast cancer, the results are encouraging at least in a small prospective controlled study (74). Currently, we do not restrict the use of standard COS with gonadotropin for IVF in women with hormone receptor (ER/PR)-negative breast cancer. In hormone receptor (ER/PR)-positive patients, however, we initiate letrozole $5 \mathrm{mg}$ on the second day of the menstrual cycle and continue it for 6-7 days (Fig. 2). Recombinant FSH (150-300 IU) with or without human menopausal gonadotropin (hMG) is given 2 days after the initiation of letrozole. A GnRH antagonist is administered when the lead follicle size reaches $14 \mathrm{~mm}$. When two to three follicles reach at least $18-19 \mathrm{~mm}$ in diameter, $\mathrm{hCG}$ is administered. Transvaginal egg retrieval is performed approximately 36 hours after hCG injection, and retrieved oocyes are fertilized by intracytoplasmic sperm injection (ICSI). After the egg retrieval, the GnRH antagonist is restarted on the same day and continued for 5-7 days to suppress $E_{2}$ levels. As most egg retrievals are performed 3-5 days after the last letrozole dose, the risk of letrozole to embryos is negligible.

\section{OOCYTE CRYOPRESERVATION}

Oocyte cryopreservation is an alternative to embryo storage and is ideal for women who do not have a partner and do not want to use donor sperm. For this procedure, the patient has to undergo ovarian stimulation and egg retrieval, the same process required for embryo cryopreservation discussed previously. Oocyte cryopreservation does not require IVF, and creation of unnecessary embryos can be prevented.

Since the first report of a live birth derived from cryopreserved human oocytes in 1986 (75), more than 900 healthy babies have been born worldwide (76). Although oocyte cryopreservation is still considered experimental in the United States, this technology has proven successful $(77,78)$. Indeed, current live-birth rates from series of frozen-thawed 
oocytes are comparable to those in frozen-thawed embryo cycles, and there was no apparent increase in the rate of congenital anomalies as compared with U.S. national statistics for natural conceptions as reported by the Centers for Disease Control $(76,79)$.

To date, most human oocytes have been cryopreserved at the metaphase II stage either by the slow freezing or vitrification method. Despite the current success, mature oocyte cryopreservation is still challenging because the metaphase II stage oocytes are extremely sensitive to temperature changes and have limited capacity for repairing cytoplasmic damage. Cryoprotectants and intracellular ice formation during a freeze-thaw procedure can lead to depolymerization of the meiotic spindle and, consequently, aneuploidy $(80,81)$. Zona hardening as a result of the premature release of cortical granules from the ooplasm is no longer an issue as the use of ICSI can circumvent this problem (82).

Vitrification is a solidification of liquid by an extreme elevation in viscosity while rapid cooling takes place and eliminates ice crystal formation and growth. Thus, it can potentially increase oocyte survival and minimize ultrastructural damage that can affect the embryo development after fertilization. Smith et al. (83) reported that embryos resulting from vitrified oocytes had significantly enhanced clinical (38\%) pregnancy rates compared with embryos resulting from slow frozen oocytes (13\%). Use of a high concentration of vitrification solutions, however, can be chemically and osmotically toxic to sensitive cells including human oocytes. Furthermore, ice formation during warming (devitrification) can be detrimental to living cells. To date, there is no standard protocol for vitrification of oocytes, which makes an analysis of published data difficult.

Since 2005, the pregnancy rates and live-birth rates have been significantly increased in both slow freezing and vitrification groups. When the data from 1998-2008 is analyzed, oocyte survival rate was higher in the vitrified group (81\%) compared with in the slow frozen group (68\%). The live-birth rate per ET was $14 \%$ and $34 \%$ in the slow frozen and vitrified group, respectively (76).

Cryopreservation of immature oocytes at the stage of germinal vesicle (GV) can be an attractive alternative to cryopreservation of mature oocytes, especially in breast cancer patients. In theory, there are several advantages of GV stage oocyte cryopreservation. First of all, it does not require full ovarian stimulation, which can be a significant benefit for breast cancer patients who cannot delay cancer treatment or who have ER+ tumor. It will also benefit women who are at high risk for ovarian hyperstimulation syndrome such as patients with polycystic ovarian syndrome.

To date, cryopreservation of immature oocytes at the GV stage has not been very successful. It appears that GV oocytes are as vulnerable to cryoinjury as mature oocytes and easily compromised for normal maturation and fertilization capacity. The possible changes after GV oocyte cryopreservation include premature chromosomal condensation, externalization of chromatin fragments into the cytoplasm, perturbations in the organization and distribution of microtubules and mitochondria, and alteration in protein synthesis activity in the cytoplasm during maturation (84). Indeed, the cytoplasmic structure in the immature oocyte can be a more critical factor for cryoinjury than the metaphase spindle of the mature oocyte. Nevertheless, immature oocyte cryopreservation followed by in vitro maturation can be a powerful tool for fertility preservation in breast cancer patients.

\section{CRYOPRESERVATION OF OVARIAN TISSUE}

Ovarian cryopreservation has become an indispensable technology for fertility preservation as it may be the only option for breast cancer patients who need treatment without delay (such as rapidly growing tumor) or who are unwilling to undergo ovarian stimulation. 
Currently, ovarian harvest via laparoscope is followed by freezing of thin slices of ovarian cortex for future use. Ovarian cortex is mainly composed of primordial follicles (the most abundant follicles in the ovary) that are relatively resistant to freeze-thaw injury (about $70 \%-80 \%$ survival) (85).

Ovarian tissue cryopreservation followed by transplantation has proven successful in both animals and humans. However, to date, only 13 healthy human babies have been born worldwide after transplantation of frozen-thawed ovarian tissue (including unpublished data) (86-92). Although this procedure is often scheduled as an urgent case, the physical and psychological state of the patient should be evaluated before the procedure. The age of the patient is a crucial factor to consider as the chance of restoration of ovarian function and fertility is closely correlated to the number of follicles in the ovarian graft. Current experience with human ovarian transplantation suggests that women over 40 may not be good candidates for ovarian tissue banking as the chance of pregnancy with transplantation is extremely low (93). Nevertheless, individual variations of ovarian reserve should not be ignored. Routine evaluation of ovarian reserve with endocrine tests as well as pelvic ultrasound (antral follicle count) may guide clinical decision making. There are several endocrine tests for ovarian reserve such as FSH and inhibin A and B, but the single best test to assess the ovarian reserve before fertility preservation in cancer patients appears to be serum anti-Müllerian hormone (AMH). AMH can be tested at any time of the menstrual cycle (unlike FSH). In our experience, patients with low serum AMH level $(<0.3 \mathrm{ng} / \mathrm{mL})$ are not good candidates for ovarian cryopreservation.

The safety of transplanting stored ovarian tissue is crucial as the risk of reintroduction of cancer cells exists in certain cancers including breast cancer. Previous studies showed that in the absence of systemic disease, occult ovarian involvement is rare in breast cancer $(58,59$, 94, 95). Most ovarian occult metastases occur in women with invasive lobular carcinoma, which is less common than the ductal subtype (95). To date, over 30 cases of ovarian transplantation have been performed in women with various cancers, including breast cancer, cervical cancer, non-Hodgkin's lymphoma, Hodgkin's lymphoma, and Ewing sarcoma, but there is no case of cancer cell reintroduction after ovarian tissue transplantation in humans. Nevertheless, the current experience with human ovarian transplantation is not sufficient to assess its safety in cancer patients.

Restoration of fertility using stored ovarian tissue is challenging and contains numerous technical and scientific problems. Hence, human ovarian transplantation should remain as an experimental procedure until its efficacy is proven. Autotransplantation of ovarian tissue can be done either orthotopically or heterotopically (96), but natural conception can be expected only with orthotopic transplantation. For orthotopic transplantation, ovarian tissue can be either transplanted onto the remaining ovary of into the peritoneal pocket of the ovarian fossa. It appears that grafting ovarian tissue in or onto the remaining ovary has advantages and more likely results in natural conception unless the size of the ovary is too small as a result of atrophy (97).

Heterotopic transplantation is an attractive alternative to ortho-topic transplantation as it can avoid invasive procedures and make the recovery of oocytes easy. It is practical and costeffective when repeated transplantation is required because of the shortened life span of the ovarian grafts. Furthermore, transplantation to the heterotopic site can be advantageous when the pelvic environment is hostile for ovarian tissue implantation owing to previous radiation or severe adhesions. The optimal site for heterotopic transplantation is still unknown. To date, heterotopic transplantation has been done into the SC tissue of the forearm (98), the space between the rectus sheath and rectus muscle $(99,100)$, and the breast tissue (99). 
The reestablishment of endocrine functions as well as ooctye retrieval after heterotopic transplantation of human ovarian tissue has been demonstrated by several investigators (98102). Nevertheless, the future of this procedure is uncertain, and, to date, no baby has been born after heterotopic transplantation.

\section{FACILITATING FERTILITY PRESERVATION CONSULTATION}

Treating physicians should initiate the discussion of the possible treatment-related effects to fertility and indicate that there are options to safeguard their future fertility potential. Women of reproductive potential and interested in learning about options for fertility preservation should be referred real time to a reproductive endocrinologist. Preferably, a fertility preservation consultation should be arranged at the time of the initial diagnosis to expedite necessary options including $\operatorname{COS}$ and oocyte retrieval for embryo cryopreservation or alternative fertility preservation techniques. This is most likely to occur in a multidisciplinary treatment environment such as a breast cancer survivorship program or similar facility that is composed of reproductive endocrinologists, breast oncologists, breast surgeons, oncology nurses, fertility nurses, genetic counselors, and social workers. Using these referral mechanisms can eliminate time delays for appointments, initiate education on the process to the patient, and provide documentation such as pathology reports or treatment plans to the referring clinician. Without the development of such a streamlined process, patients and providers will experience frustration and unnecessary time delays.

Nevertheless, many patients fail to pursue fertility preservation options owing to two main barriers, time and cost. Of note, most procedures for fertility preservation are not covered by insurance in the United States.

\section{CONCLUSION}

Long-term survival is expected in most women with breast cancer as a result of advances in cancer treatment. For young cancer survivors who have not completed their family, fertility is a crucial issue. Informed decision making regarding future fertility can lead to decreased patient regret and improved quality of life. Use of less gonadotoxic regimens for adjuvant or neoadjuvant chemotherapy may be considered in young breast cancer patients with favorable tumors who are in their reproductive years. When there is a high risk of losing fertility with aggressive cancer treatment, currently available options for fertility preservation should be discussed. Embryo cryopreservation is a well-established technology and suitable for women who have a partner. Oocyte cryopreservation is an alternative option that can avoid ethical and legal issues (unlike embryo cryopreservation). However, neither embryo nor oocyte cryopreservation is a practical option for women who cannot delay cancer treatment. In addition, COS is required for both embryo and oocyte cryopreservation, and an increase in peak $\mathrm{E}_{2}$ levels with COS may accelerate the tumor growth in ER+ breast cancer. The alternative COS strategy using tamoxifen or letrozole in conjunction with gonadotropin can suppress the elevation of $\mathrm{E}_{2}$ levels and may be considered for women with $\mathrm{ER}+$ tumor. Where embryo or oocyte cryopreservation is not indicated, cryopreservation of ovarian tissue can be a reasonable alternative, without the worry of delaying cancer treatment or increasing $\mathrm{E}_{2}$ levels. Fertility specialists should work closely with breast cancer treatment teams to provide options for fertility preservation before the initiation of cancer treatment in young women with breast cancer. A multidisciplinary program such as a breast cancer survivorship program will facilitate timely communications between oncologists and fertility specialists as well as effective transmission of information to health care providers and patients. 


\section{REFERENCES}

1. Anders CK, Johnson R, Litton J, Phillips M, Bleyer A. Breast cancer before age 40 years. Semin Oncol. 2009; 36:237-49. [PubMed: 19460581]

2. Hayat MJ, Howlader N, Reichman ME, Edwards BK. Cancer statistics, trends, and multiple primary cancer analyses from the Surveillance, Epidemiology, and End Results (SEER) Program. Oncologist. 2007; 12:20-37. [PubMed: 17227898]

3. Blakely LJ, Buzdar AU, Lozada JA, Shullaih SA, Hoy E, Smith TL, et al. Effects of pregnancy after treatment for breast carcinoma on survival and risk of recurrence. Cancer. 2004; 100:465-9. [PubMed: 14745861]

4. Mueller BA, Simon MS, Deapen D, Kamineni A, Malone KE, Daling JR. Childbearing and survival after breast carcinoma in young women. Cancer. 2003; 98:1131-40. [PubMed: 12973836]

5. Cvancarova M, Samuelsen SO, Magelssen H, Fossa SD. Reproduction rates after cancer treatment: experience from the Norwegian radium hospital. J Clin Oncol. 2009; 27:334-43. [PubMed: 19075285]

6. Partridge AH, Gelber S, Peppercorn J, Sampson E, Knudsen K, Laufer M, et al. Web-based survey of fertility issues in young women with breast cancer. J Clin Oncol. 2004; 22:4174-83. [PubMed: 15483028]

7. Velentgas P, Daling JR, Malone KE, Weiss NS, Williams MA, Self SG, et al. Pregnancy after breast carcinoma: outcomes and influence on mortality. Cancer. 1999; 85:2424-32. [PubMed: 10357413]

8. Largillier R, Savignoni A, Gligorov J, Chollet P, Guilhaume MN, Spielmann M, et al. Prognostic role of pregnancy occurring before or after treatment of early breast cancer patients aged <35 years: a GET(N)A Working Group analysis. Cancer. 2009; 115:5155-65. [PubMed: 19691088]

9. Ives A, Saunders C, Bulsara M, Semmens J. Pregnancy after breast cancer: population based study. Br Med J. 2007; 334:194. [PubMed: 17158581]

10. Rosenberg R, Levy-Schwartz R. Breast cancer in women younger than 40 years. Int J Fertil Womens Med. 2003; 48:200-5. [PubMed: 14626376]

11. Goldhirsch A, Ingle JN, Gelber RD, Coates AS, Thurlimann B, Senn HJ. Thresholds for therapies: highlights of the St Gallen International Expert Consensus on the primary therapy of early breast cancer 2009. Ann Oncol. 2009; 20:1319-29. [PubMed: 19535820]

12. Gnant M, Greil R, Kubista E. The impact of treatment-induced amenorrhea on survival of premenopausal patients with endocrine-responsive breast cancer: 10-year result of ABCSG-05 (CMF vs. goserelin p tamoxifen). Breast Cancer Res Treat. 2006; 100:S10-1.

13. Vanhuyse M, Fournier C, Bonneterre J. Chemotherapy-induced amenorrhea: influence on diseasefree survival and overall survival in receptor-positive premenopausal early breast cancer patients. Ann Oncol. 2005; 16:1283-8. [PubMed: 15870085]

14. Colleoni M, Gelber S, Goldhirsch A, Aebi S, Castiglione-Gertsch M, Price KN, et al. Tamoxifen after adjuvant chemotherapy for premenopausal women with lymph node-positive breast cancer: International Breast Cancer Study Group Trial 13-93. J Clin Oncol. 2006; 24:1332-41. [PubMed: 16505417]

15. Goel S, Sharma R, Hamilton A, Beith J. LHRH agonists for adjuvant therapy of early breast cancer in premenopausal women. Cochrane Database Syst Rev. 2009; 7(4):CD004562. [PubMed: 19821328]

16. Petrek JA, Naughton MJ, Case LD, Paskett ED, Naftalis EZ, Singletary SE, et al. Incidence, time course, and determinants of menstrual bleeding after breast cancer treatment: a prospective study. J Clin Oncol. 2006; 24:1045-51. [PubMed: 16476708]

17. Walshe JM, Denduluri N, Swain SM. Amenorrhea in premenopausal women after adjuvant chemotherapy for breast cancer. J Clin Oncol. 2006; 24:5769-79. [PubMed: 17130515]

18. Gerber B, Dieterich M, Muller H, Reimer T. Controversies in preservation of ovary function and fertility in patients with breast cancer. Breast Cancer Res Treat. 2008; 108:1-7. [PubMed: 17457668]

19. Hickey M, Peate M, Saunders CM, Friedlander M. Breast cancer in young women and its impact on reproductive function. Hum Reprod Update. 2009; 15:323-39. [PubMed: 19174449] 
20. Jemal A, Siegel R, Ward E, Hao Y, Xu J, Thun MJ. Cancer statistics, 2009. CA Cancer J Clin. 2009; 59:225-49. [PubMed: 19474385]

21. Jemal A, Siegel R, Xu J, Ward E. Cancer Statistics, 2010. CA Cancer J Clin. 2010; 60:277-300. [PubMed: 20610543]

22. Ganz PA, Greendale GA, Petersen L, Kahn B, Bower JE. Breast cancer in younger women: reproductive and late health effects of treatment. J Clin Oncol. 2003; 21:4184-93. [PubMed: 14615446]

23. Phillips KA, Osborne RH, Giles GG, Dite GS, Apicella C, Hopper JL, et al. Psychosocial factors and survival of young women with breast cancer: a population-based prospective cohort study. $\mathrm{J}$ Clin Oncol. 2008; 26:4666-71. [PubMed: 18824713]

24. Gorman JR, Malcarne VL, Roesch SC, Madlensky L, Pierce JP. Depressive symptoms among young breast cancer survivors: the importance of reproductive concerns. Breast Cancer Res Treat. 2010; 123:477-85. [PubMed: 20130979]

25. Thewes B, Butow P, Girgis A, Pendlebury S. The psychosocial needs of breast cancer survivors; a qualitative study of the shared and unique needs of younger versus older survivors. Psychooncology. 2004; 13:177-89. [PubMed: 15022153]

26. Kaufmann M, Hortobagyi GN, Goldhirsch A, Scholl S, Makris A, Valagussa P, et al. Recommendations from an international expert panel on the use of neoadjuvant (primary) systemic treatment of operable breast cancer: an update. J Clin Oncol. 2006; 24:1940-9. [PubMed: 16622270]

27. Fredholm H, Eaker S, Frisell J, Holmberg L, Fredriksson I, Lindman H. Breast cancer in young women: poor survival despite intensive treatment. PLoS One. 2009; 4:e7695. [PubMed: 19907646]

28. Hartley MC, McKinley BP, Rogers EA, Kalbaugh CA, Messich HS, Blackhurst DW, et al. Differential expression of prognostic factors and effect on survival in young (< or $1 / 440)$ breast cancer patients: a case-control study. Am Surg. 2006; 72:1189-94. [PubMed: 17216817]

29. Meneses K, McNees P, Azuero A, Jukkala A. Development of the Fertility and Cancer Project: an Internet approach to help young cancer survivors. Oncol Nurs Forum. 2010; 37:191-7. [PubMed: 20189924]

30. EBCTCG. Effects of chemotherapy and hormonal therapy for early breast cancer on recurrence and 15-year survival: an overview of the randomised trials. Lancet. 2005; 365:1687-717. [PubMed: 15894097]

31. Perou CM, Sorlie T, Eisen MB, van de Rijn M, Jeffrey SS, Rees CA, et al. Molecular portraits of human breast tumours. Nature. 2000; 406:747-52. [PubMed: 10963602]

32. Hugh J, Hanson J, Cheang MC, Nielsen TO, Perou CM, Dumontet C, et al. Breast cancer sub-types and response to docetaxel in node-positive breast cancer: use of an immunohistochemical definition in the BCIRG 001 trial. J Clin Oncol. 2009; 27:1168-76. [PubMed: 19204205]

33. Paik S, Shak S, Tang G, Kim C, Baker J, Cronin M, et al. A multigene assay to predict recurrence of tamoxifen-treated, node-negative breast cancer. N Engl J Med. 2004; 351:2817-26. [PubMed: 15591335]

34. Sparano JA, Wang M, Martino S, Jones V, Perez EA, Saphner T, et al. Weekly paclitaxel in the adjuvant treatment of breast cancer. N Engl J Med. 2008; 358:1663-71. [PubMed: 18420499]

35. Parker JS, Mullins M, Cheang MC, Leung S, Voduc D, Vickery T, et al. Supervised risk predictor of breast cancer based on intrinsic subtypes. J Clin Oncol. 2009; 27:1160-7. [PubMed: 19204204]

36. Albain KS, Paik S, van't Veer L. Prediction of adjuvant chemotherapy benefit in endocrine responsive, early breast cancer using multigene assays. Breast. 2009; 18(Suppl 3):S141-5. [PubMed: 19914534]

37. Piccart-Gebhart MJ, Procter M, Leyland-Jones B, Goldhirsch A, Untch M, Smith I, et al. Trastuzumab after adjuvant chemotherapy in HER2-positive breast cancer. N Engl J Med. 2005; 353:1659-72. [PubMed: 16236737]

38. Brewster AM, Hortobagyi GN, Broglio KR, Kau SW, Santa-Maria CA, Arun B, et al. Residual risk of breast cancer recurrence 5 years after adjuvant therapy. J Natl Cancer Inst. 2008; 100:1179-83. [PubMed: 18695137] 
39. Goss PE, Muss HB, Ingle JN, Whelan TJ, Wu M. Extended adjuvant endocrine therapy in breast cancer: current status and future directions. Clin Breast Cancer. 2008; 8:411-7. [PubMed: 18952554]

40. Penault-Llorca F, Andre F, Sagan C, Lacroix-Triki M, Denoux Y, Verriele V, et al. Ki67 expression and docetaxel efficacy in patients with estrogen receptor-positive breast cancer. J Clin Oncol. 2009; 27:2809-15. [PubMed: 19380452]

41. Bedard PL, Di Leo A, Piccart-Gebhart MJ. Taxanes: optimizing adjuvant chemotherapy for earlystage breast cancer. Nat Rev Clin Oncol. 2010; 7:22-36. [PubMed: 19997076]

42. Gnant M, Mlineritsch B, Schippinger W, Luschin-Ebengreuth G, Postlberger S, Menzel C, et al. Endocrine therapy plus zoledronic acid in premenopausal breast cancer. N Engl J Med. 2009; 360:679-91. [PubMed: 19213681]

43. Goldhirsch A, Gelber RD, Castiglione M. The magnitude of endocrine effects of adjuvant chemotherapy for premenopausal breast cancer patients. The International Breast Cancer Study Group. Ann Oncol. 1990; 1:183-8. [PubMed: 2261364]

44. Bonadonna G, Valagussa P, Moliterni A, Zambetti M, Brambilla C. Adjuvant cyclophosphamide, methotrexate, and fluorouracil in node-positive breast cancer: the results of 20 years of follow-up. N Engl J Med. 1995; 332:901-6. [PubMed: 7877646]

45. Fisher B, Brown AM, Dimitrov NV, Poisson R, Redmond C, Margolese RG, et al. Two months of doxorubicin-cyclophosphamide with and without interval reinduction therapy compared with 6 months of cyclophosphamide, methotrexate, and fluorouracil in positive-node breast cancer patients with tamoxifen-nonresponsive tumors: results from the National Surgical Adjuvant Breast and Bowel Project B-15. J Clin Oncol. 1990; 8:1483-96. [PubMed: 2202791]

46. Bines J, Oleske DM, Cobleigh MA. Ovarian function in premenopausal women treated with adjuvant chemotherapy for breast cancer. J Clin Oncol. 1996; 14:1718-29. [PubMed: 8622093]

47. Jones S, Holmes FA, O'Shaughnessy J, Blum JL, Vukelja SJ, McIntyre KJ, et al. Docetaxel with cyclophosphamide is associated with an overall survival benefit compared with doxorubicin and cyclophosphamide: 7-year follow-up of US oncology research trial 9735. J Clin Oncol. 2009; 27:1177-83. [PubMed: 19204201]

48. Levine MN, Bramwell VH, Pritchard KI, Norris BD, Shepherd LE, Abu-Zahra H, et al. Randomized trial of intensive cyclophosphamide, epirubicin, and fluorouracil chemotherapy compared with cyclophosphamide, methotrexate, and fluorouracil in premenopausal women with node-positive breast cancer. National Cancer Institute of Canada Clinical Trials Group. J Clin Oncol. 1998; 16:2651-8. [PubMed: 9704715]

49. Hortobagyi GN, Buzdar AU, Marcus CE, Smith TL. Immediate and long-term toxicity of adjuvant chemotherapy regimens containing doxorubicin in trials at M.D. Anderson Hospital and Tumor Institute. NCI Monogr. 1986:105-9. [PubMed: 3534581]

50. Swain SM, Land SR, Ritter MW, Costantino JP, Cecchini RS, Mamounas EP, et al. Amenorrhea in premenopausal women on the doxorubicin-andcyclophosphamide-followed-by-docetaxel arm of NSABP B-30 trial. Breast Cancer Res Treat. 2009; 113:315-20. [PubMed: 18302020]

51. Fornier MN, Modi S, Panageas KS, Norton L, Hudis C. Incidence of chemotherapy-induced, longterm amenorrhea in patients with breast carcinoma age 40 years and younger after adjuvant anthracycline and taxane. Cancer. 2005; 104:1575-9. [PubMed: 16134178]

52. Tham YL, Sexton K, Weiss H, Elledge R, Friedman LC, Kramer R. The rates of chemotherapyinduced amenorrhea in patients treated with adjuvant doxorubicin and cyclophosphamide followed by a taxane. Am J Clin Oncol. 2007; 30:126-32. [PubMed: 17414460]

53. Perez-Fidalgo JA, Rosello S, Garcia-Garre E, Jorda E, Martin-Martorell P, Bermejo B, et al. Incidence of chemotherapy-induced amenorrhea in hormone-sensitive breast cancer patients: the impact of addition of taxanes to anthracycline-based regimens. Breast Cancer Res Treat. 2010; 120:245-51. [PubMed: 19575291]

54. Berliere M, Dalenc F, Malingret N, Vindevogel A, Piette P, Roche H, et al. Incidence of reversible amenorrhea in women with breast cancer undergoing adjuvant anthracycline-based chemotherapy with or without docetaxel. BMC Cancer. 2008; 8:56. [PubMed: 18291033]

55. Slamon D, Pegram M. Rationale for trastuzumab (Herceptin) in adjuvant breast cancer trials. Semin Oncol. 2001; 28:13-9. [PubMed: 11301370] 
56. Costa RB, Kurra G, Greenberg L, Geyer CE. Efficacy and cardiac safety of adjuvant trastuzumabbased chemotherapy regimens for HER2-positive early breast cancer. Ann Oncol. 2010; 21:215360. [PubMed: 20351072]

57. Ismail-Khan R, Bui MM. A review of triple-negative breast cancer. Cancer Control. 2010; 17:1736. [PubMed: 20664514]

58. Rabban JT, Barnes M, Chen LM, Powell CB, Crawford B, Zaloudek CJ. Ovarian pathology in risk-reducing salpingo-oophorectomies from women with BRCA mutations, emphasizing the differential diagnosis of occult primary and metastatic carcinoma. Am J Surg Pathol. 2009; 33:1125-36. [PubMed: 19440148]

59. Sanchez-Serrano M, Novella-Maestre E, Rosello-Sastre E, Camarasa N, Teruel J, Pellicer A. Malignant cells are not found in ovarian cortex from breast cancer patients undergoing ovarian cortex cryopreservation. Hum Reprod. 2009; 24:2238-43. [PubMed: 19491203]

60. Badawy A, Elnashar A, El-Ashry M, Shahat M. Gonadotropin-releasing hormone agonists for prevention of chemotherapy-induced ovarian damage: prospective randomized study. Fertil Steril. 2009; 91:694-7. [PubMed: 18675959]

61. Pereyra Pacheco B, Mendez Ribas JM, Milone G, Fernandez I, Kvicala R, Mila T, et al. Use of $\mathrm{GnRH}$ analogs for functional protection of the ovary and preservation of fertility during cancer treatment in adolescents: a preliminary report. Gynecol Oncol. 2001; 81:391-7. [PubMed: 11371127]

62. Blumenfeld Z, Eckman A. Preservation offertility and ovarian function and minimization of chemotherapy-induced gonadotoxicity in young women by GnRH-a. J Natl Cancer Inst Monogr. 2005:40-3. [PubMed: 15784821]

63. Dann EJ, Epelbaum R, Avivi I, Ben Shahar M, Haim N, Rowe JM, et al. Fertility and ovarian function are preserved in women treated with an intensified regimen of cyclophosphamide, adriamycin, vincristine and prednisone (Mega-CHOP) for non-Hodgkin lymphoma. Hum Reprod. 2005; 20:2247-9. [PubMed: 15817583]

64. Somers EC, Marder W, Christman GM, Ognenovski V, McCune WJ. Use of a gonadotropinreleasing hormone analog for protection against premature ovarian failure during cyclophosphamide therapy in women with severe lupus. Arthritis Rheum. 2005; 52:2761-7. [PubMed: 16142702]

65. Castelo-Branco C, Nomdedeu B, Camus A, Mercadal S, Martinez de Osaba MJ, Balasch J. Use of gonadotropin-releasing hormone agonists in patients with Hodgkin's disease for preservation of ovarian function and reduction of gonadotoxicity related to chemotherapy. Fertil Steril. 2007; 87:702-5. [PubMed: 17173900]

66. Blumenfeld Z, Avivi I, Eckman A, Epelbaum R, Rowe JM, Dann EJ. Gonadotropin-releasing hormone agonist decreases chemotherapy-induced gonadotoxicity and premature ovarian failure in young female patients with Hodgkin lymphoma. Fertil Steril. 2008; 89:166-73. [PubMed: 17601603]

67. Huser M, Crha I, Ventruba P, Hudecek R, Zakova J, Smardova L, et al. Prevention of ovarian function damage by a GnRH analogue during chemotherapy in Hodgkin lymphoma patients. Hum Reprod. 2008; 23:863-8. [PubMed: 18258763]

68. Nitzschke M, Raddatz J, Bohlmann MK, Stute P, Strowitzki T, von Wolff M. GnRH analogs do not protect ovaries from chemotherapy-induced ultra-structural injury in Hodgkin's lymphoma patients. Arch Gynecol Obstet. 2009; 282:83-8. [PubMed: 19967405]

69. Waxman JH, Ahmed R, Smith D, Wrigley PF, Gregory W, Shalet S, et al. Failure to preserve fertility in patients with Hodgkin's disease. Cancer Che-mother Pharmacol. 1987; 19:159-62.

70. Giuseppe L, Attilio G, Edoardo DN, Loredana G, Cristina L, Vincenzo L. Ovarian function after cancer treatment in young women affected by Hodgkin disease (HD). Hematology. 2007; 12:1417. [PubMed: 17454195]

71. Kim SS, Lee JR, Jee BC, Suh CS, Kim SH, Ting A, Petroff B. Use of hormonal protection for chemo-therapy-induced gonadotoxicity. Clin Obstet Gynecol. 2010; 53:740-52. [PubMed: 21048441]

72. Milliken EL, Lozada KL, Johnson E, Landis MD, Seachrist DD, Whitten I, et al. Ovarian hyperstimulation induces centrosome amplification and aneuploid mammary tumors independently 
of alterations in p53 in a transgenic mouse model of breast cancer. Oncogene. 2008; 27:1759-66. [PubMed: 17891171]

73. Oktay K, Buyuk E, Libertella N, Akar M, Rosenwaks Z. Fertility preservation in breast cancer patients: a prospective controlled comparison of ovarian stimulation with tamoxifen and letrozole for embryo cryopreservation. J Clin Oncol. 2005; 23:4347-53. [PubMed: 15824416]

74. Azim AA, Costantini-Ferrando M, Oktay K. Safety of fertility preservation by ovarian stimulation with letrozole and gonadotropins in patients with breast cancer: a prospective controlled study. $\mathrm{J}$ Clin Oncol. 2008; 26:2630-5. [PubMed: 18509175]

75. Chen C. Pregnancy after human oocyte cryopreservation. Lancet. 1986; 1:884-6. [PubMed: 2870356]

76. Noyes N, Porcu E, Borini A. Over 900 oocyte cryo-preservation babies born with no apparent increase in congenital anomalies. Reprod Biomed Online. 2009; 18:769-76. [PubMed: 19490780]

77. Grifo JA, Noyes N. Delivery rate using cryopre-served oocytes is comparable to conventional in vitro fertilization using fresh oocytes: potential fertility preservation for female cancer patients. Fertil Steril. 2010; 93:391-6. [PubMed: 19439285]

78. Nagy ZP, Chang CC, Shapiro DB, Bernal DP, Elsner CW, Mitchell-Leef D, et al. Clinical evaluation of the efficiency of an oocyte donation program using egg cryo-banking. Fertil Steril. 2009; 92:520-6. [PubMed: 18692830]

79. Noyes N, Boldt J, Nagy ZP. Oocyte cryopreservation: is it time to remove its experimental label? J Assist Reprod Genet. 2010; 27:69-74. [PubMed: 20140641]

80. Baka SG, Toth TL, Veeck LL, Jones HW Jr, Muasher SJ, Lanzendorf SE. Evaluation of the spindle apparatus of in-vitro matured human oocytes following cryopreservation. Hum Reprod. 1995; 10:1816-20. [PubMed: 8582988]

81. Pickering SJ, Braude PR, Johnson MH, Cant A, Currie J. Transient cooling to room temperature can cause irreversible disruption of the meiotic spindle in the human oocyte. Fertil Steril. 1990; 54:102-8. [PubMed: 2358076]

82. Kim SS. Fertility preservation in female cancer patients: current developments and future directions. Fertil Steril. 2006; 85:1-11. [PubMed: 16412718]

83. Smith GD, Serafini PC, Fioravanti J, Yadid I, Coslovsky M, Hassun P, et al. Prospective randomized comparison of human oocyte cryopreservation with slow-rate freezing or vitrification. Fertil Steril. 2010; 94:2088-95. [PubMed: 20171613]

84. Van Blerkom J. Maturation at high frequency of germinal-vesicle-stage mouse oocytes after cryopreservation: alterations in cytoplasmic, nuclear, nucleolar and chromosomal structure and organization associated with vitrification. Hum Reprod. 1989; 4:883-98. [PubMed: 2693483]

85. Newton H, Aubard Y, Rutherford A, Sharma V, Gosden R. Low temperature storage and grafting of human ovarian tissue. Hum Reprod. 1996; 11:1487-91. [PubMed: 8671490]

86. Donnez J, Dolmans MM, Demylle D, Jadoul P, Pirard C, Squifflet J, et al. Livebirth after orthotopic transplantation of cryopreserved ovarian tissue. Lancet. 2004; 364:1405-10. [PubMed: 15488215]

87. Meirow D, Levron J, Eldar-Geva T, Hardan I, Fridman E, Zalel Y, et al. Pregnancy after transplantation of cryopreserved ovarian tissue in a patient with ovarian failure after chemotherapy. N Engl J Med. 2005; 353:318-21. [PubMed: 15983020]

88. Demeestere I, Simon P, Emiliani S, Delbaere A, Englert Y. Fertility preservation: successful trans plantation of cryopreserved ovarian tissue in a young patient previously treated for Hodgkin's disease. Oncologist. 2007; 12:1437-42. [PubMed: 18165621]

89. Andersen CY, Rosendahl M, Byskov AG, Loft A, Ottosen C, Dueholm M, et al. Two successful pregnancies following autotransplantation of frozen/-thawed ovarian tissue. Hum Reprod. 2008; 23:2266-72. [PubMed: 18603535]

90. Roux C, Amiot C, Agnani G, Aubard Y, Rohrlich PS, Piver P. Live birth after ovarian tissue autograft in a patient with sickle cell disease treated by allogeneic bone marrow transplantation. Fertil Steril. 2010; 93(2413):e15-9. [PubMed: 20117783]

91. Sanchez-Serrano M, Crespo J, Mirabet V, Cobo AC, Escriba MJ, Simon C, et al. Twins born after transplantation of ovarian cortical tissue and oocyte vitrification IVF outcome in patients with orthotopically transplanted ovarian tissue. Fertil Steril. 2009; 30:30. 
92. Silber SJ, DeRosa M, Pineda J, Lenahan K, Grenia D, Gorman K, et al. A series of monozygotic twins discordant for ovarian failure: ovary transplantation (cortical versus microvascular) and cryopreservation. Hum Reprod. 2008; 23:1531-7. [PubMed: 18285322]

93. von Wolff M, Donnez J, Hovatta O, Keros V, Maltaris T, Montag M, et al. Cryopreservation and autotransplantation of human ovarian tissue prior to cytotoxic therapy-a technique in its infancy but already successful in fertility preservation. Eur J Cancer. 2009; 45:1547-53. [PubMed: 19264478]

94. Perrotin F, Marret H, Bouquin R, Fischer-Perrotin N, Lansac J, Body G. Incidence, diagnosis and prognosis of ovarian metastasis in breast cancer. Gynecol Obstet Fertil. 2001; 29:308-15. [PubMed: 11338136]

95. Borst MJ, Ingold JA. Metastatic patterns of invasive lobular versus invasive ductal carcinoma of the breast. Surgery. 1993; 114:637-41. [PubMed: 8211676]

96. Kim SS, Battaglia DE, Soules MR. The future of human ovarian cryopreservation and transplantation: fertility and beyond. Fertil Steril. 2001; 75:1049-56. [PubMed: 11384626]

97. Demeestere I, Simon P, Emiliani S, Delbaere A, Englert Y. Orthotopic and heterotopic ovarian tissue transplantation. Hum Reprod Update. 2009; 15:649-65. [PubMed: 19474206]

98. Oktay K, Economos K, Kan M, Rucinski J, Veeck L, Rosenwaks Z. Endocrine function and oocyte retrieval after autologous transplantation of ovarian cortical strips to the forearm. JAMA. 2001; 286:1490-3. [PubMed: 11572742]

99. Kim SS, Hwang IT, Lee HC. Heterotopic autotrans-plantation of cryobanked human ovarian tissue as a strategy to restore ovarian function. Fertil Steril. 2004; 82:930-2. [PubMed: 15482772]

100. Kim SS, Lee WS, Chung MK, Lee HC, Lee HH, Hill D. Long-term ovarian function and fertility after heterotopic autotransplantation of cryobanked human ovarian tissue: 8-year experience in cancer patients. Fertil Steril. 2009; 91:2349-54. [PubMed: 18675964]

101. Rosendahl M, Loft A, Byskov AG, Ziebe S, Schmidt KT, Andersen AN, et al. Biochemical pregnancy after fertilization of an oocyte aspirated from a heterotopic autotransplant of cryopreserved ovarian tissue: case report. Hum Reprod. 2006; 21:2006-9. [PubMed: 16684840]

102. Oktay K, Buyuk E, Veeck L, Zaninovic N, Xu K, Takeuchi T, et al. Embryo development after hetero-topic transplantation of cryopreserved ovarian tissue. Lancet. 2004; 363:837-40. [PubMed: 15031026] 


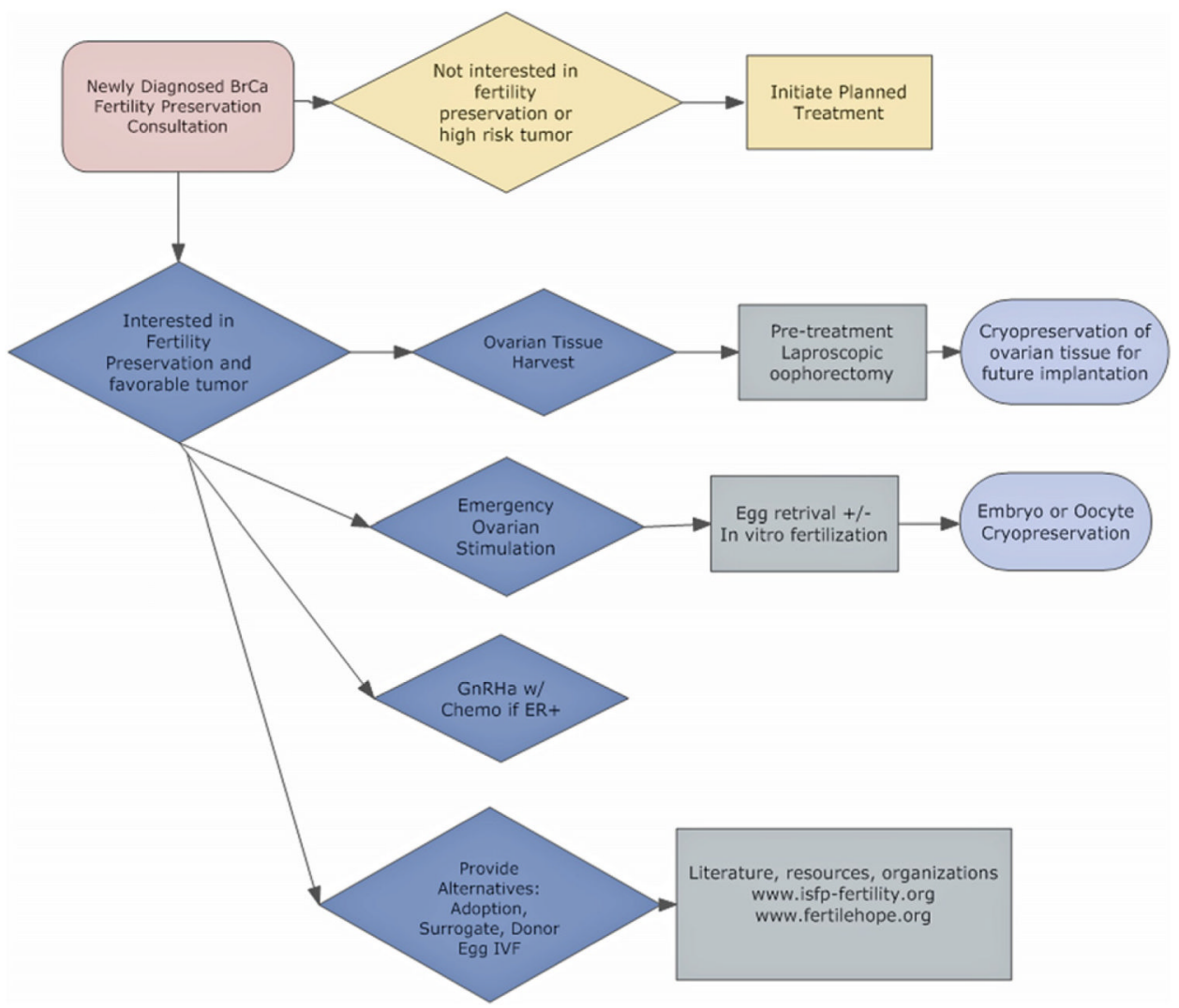

FIGURE 1.

Fertility preservation options for breast cancer patients. Thorough consultation is imperative for every woman with cancer before she makes a decision for fertility preservation. 


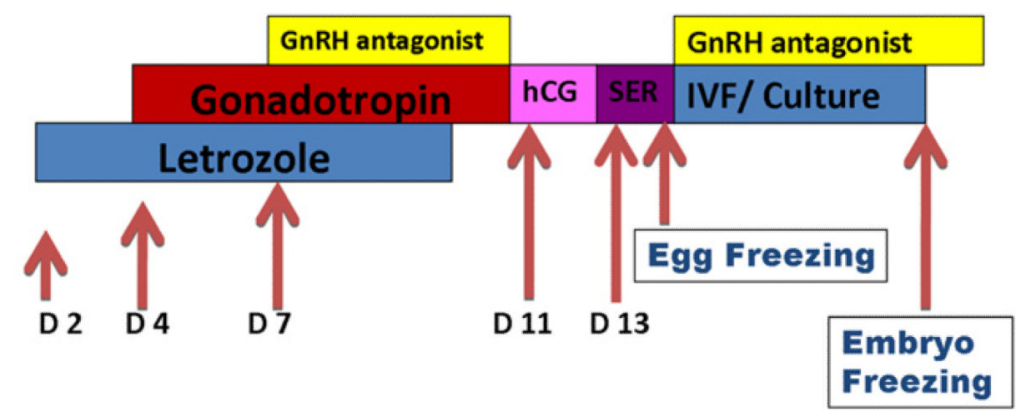

FIGURE 2.

Protocol for COS for embryo/oocyte cryopreservation in breast cancer patients (d: cycle day; SER: ultrasound-guided egg retrieval). 
TABLE 1

Subtypes of breast cancer by biologic characteristics.

\begin{tabular}{|c|c|c|c|c|}
\hline Subtypes & Biologic characteristics & $\begin{array}{l}\text { Incidence in } \\
\text { all } \\
\text { population }\end{array}$ & Treatment for young women & Comments \\
\hline Luminal A & $\begin{array}{l}\text { Strongly ER+,PR+, low } \\
\text { Ki-67, HER-2 Neu negative }\end{array}$ & $\sim 15 \%$ & $\begin{array}{l}\text { Tamoxifen with or without } \\
\text { oophorectomy or LHRH agonist } \\
\text { for } 5 \text { years and invasive } \pm \text { IV } \\
\text { bisphosphonate } 2-3 \text { years } \pm \\
\text { adjuvant chemotherapy for } \\
\text { larger tumors }\end{array}$ & $\begin{array}{l}\text { Any ER staining is } \\
\text { positive, but luminal A } \\
\text { tumors strongly ER and } \\
\text { PR+ }\end{array}$ \\
\hline Luminal B & $\begin{array}{l}\text { ER+,PR+ but unfavorable } \\
\text { characteristics such as low } \\
\text { level ER or PR, high Ki- } 67 \text { or } \\
\text { growth factor receptor Her-2, } \\
\text { or EGFR + }\end{array}$ & $\sim 60 \%$ & $\begin{array}{l}\text { Adjunct chemotherapy with four } \\
\text { cycles AC }+ \text { four cycles T }(\sim 12 \\
\text { weeks }) \text { or six TAC or six FEC/ } \\
\text { FAC for invasive tumors } \pm 1 \mathrm{~cm} \text {. } \\
\text { Followed by } 5 \text { years of } \\
\text { antihormone therapy } \pm \text { IV } \\
\text { bisphosphonate as for luminal } \\
\text { Aforany invasive }\end{array}$ & $\begin{array}{l}\text { Tumor }>2 \mathrm{~cm} \text { or node } \\
\text { positive consider } \\
\text { neoadjuvant therapy } \\
\text { instead of adjuvant. } \\
\text { Tumors that are ER+ PR+ } \\
\text { and HER-2 + probably } \\
\text { type of luminal B and } \\
\text { should also receive } \\
\text { traztuzamab. }\end{array}$ \\
\hline HER-2+ & ER-, HER-2+ & $\begin{array}{l}\sim 10 \% \text { (more } \\
\text { frequent in } \\
\text { young } \\
\text { women) }\end{array}$ & $\begin{array}{l}\text { Adjuvant chemotherapy with six } \\
\text { cycles of taxotere + carboplatin } \\
+ \text { trastuzamab followed by } \\
\text { trastuzamab alone for total of } 1 \\
\text { year or four cycles of AC } \\
\text { followed by four cycles of T + } \\
\text { trastuzamab followed by } \\
\text { trastuzamb for total } 1 \text { year, }\end{array}$ & $\begin{array}{l}\text { HER-2 Over-expressed by } \\
\text { fluorescence in situ } \\
\text { hybridization or } 3+\text { by } \\
\text { immunochemistry }\end{array}$ \\
\hline Basal-like (triple negative) & ER-, PR-, HER-2- & $\begin{array}{l}\sim 15 \% \text { (more } \\
\text { frequent in } \\
\text { young } \\
\text { women) }\end{array}$ & $\begin{array}{l}\text { Adjunct chemotherapy if tumor } \\
>1 \text { cmor high grade }\end{array}$ & \\
\hline
\end{tabular}

Kim. Breast cancer and fertility preservation. Fertil Steril 2011. 